\title{
РОЗВИТОК ПОЛІТИЧНИХ І ДИПЛОМАТИЧНИХ ВІДНОСИНИ МІЖ КНР ТА КРАЇНАМИ ЛАТИНСЬКОЇ АМЕРИКИ (1990-ті - 2020 рр.)
}

\begin{abstract}
Анотація: Дана стаття присвячена висвітленню розвитку політичних і дипломатичних відносин між Китайською Народною Республікою та крайнами Латинської Америки. Прагнучи стабільності енергетичної безпеки та світового лідерства уряд КНР ще на початку 1990-х рр. проголошує співпраџю з краӥнами цього континенту одними з пріоритетних, хоча налагодження контактів і встановлення дипломатичних відносин було розпочате ще до розпаду біполярної системи міжнародних відносин. Використовуючи принцип «м'якої сили», КНР інтенсивно розвиває дані відносини $з$ латиноамериканськими країнами. Про важливість яких говорять і самі иі країни, називаючи Китай пріоритетним партнером. Дана стаття є спробою у хронологічній послідовності висвітлити розвиток відносин мізк краӥнами до 2020 р., вказавши ключові аспекти цієї співпраці.
\end{abstract}

Ключові слова: КНР, Латинська Америка, ЛАКБ, дипломатія «м’якої сили», політичні та дипломатичні відносини

На сьогоднішній день одним з пріоритетних напрямів зовнішньої політики Китайської Народної Республіки є латиноамериканський вектор, який за останні 20 років розширився у геометричній прогресії. Ще на початку 60-х рр. XX ст. Китай починає проявляти інтерес до країн Латинської Америки, серед яких провідне місце займає прокомуністична Куба. А упродовж 1970-х рр. Китай активно розвиває відносини з іншими країнами регіону1.

Аналізуючи стан наукової розробки теми, варто відмітити, що серед вітчизняних дослідників Китай вже давно зайняв чільне місце. Однак, що стосується китайськолатиноамериканських відносин, то тут праць не так вже й багато. Можна виділити напрацювання К. Вакарчук², Н. Валігури ${ }^{3}$ й ін. Досить грунтовними є праці американських,

\footnotetext{
* Вовчук Людмила Анатоліївна - кандидат історичних наук, доцент кафедри міжнародних відносин та зовнішньої політики Чорноморського нащіонального університету імені Петра Могили (м. Миколаїв) ORCID: https://orcid.org/0000-0002-8324-5235; e-mail: luda_vovchuk@ukr.net

Кравеиь Олег Анатолійович - магістр міжнародних відносин Чорноморського національного університету імені Петра Могили (м. Миколаїв)

ORCID: https://orcid.org/0000-0003-1155-9814; e-mail: kara22spn@gmail.com

${ }^{1}$ Johnson G., Lin Z. Sino-Latin American Relations: A Comparison of Expert and Educated Youth Views of Latin America // Journal of China and International Relations (JCIR). 2015. Vol. 3. №1. P. 27.

${ }^{2}$ Вакарчук К. Латиноамериканський вектор зовнішньої політики Китаю // Борисфен Інтел: незалежний аналітичний центр геополітичних досліджень. 2020. 16 червня. URL: https://bintel.org.ua/publication/regions/america/latinoamerikanskij-vektor-politiki-kitayu/; $\quad$ Вакарчук K.В. Зовнішня політика Бразилії в період правління Д. Руссефф // Актуальні проблеми політики. 2014. Вип.. 53. C. $142-148$.

${ }^{3}$ Валігура Н.Ю. Стратегія та доктрина зростання китайського впливу у світі // Наукові записки студентів та аспірантів. 2020. Вип. 5. С. 43-51.
} 
китайських, латиноамериканських дослідників. Значний інтерес спостерігається і серед європейських науковців. На особливу увагу заслуговує робота 3. Лін і Г. Джонсона ${ }^{4}$ в якій вони демонструють китайські погляди на стрімко зростаючі політичні й економічні зв'язки з Латинською Америкою, підкреслюючи, що переважна увага Китаю зосереджена саме на економічних відносинах з країнами Латинської Америки. Поєднуючи емпіричні прийоми та політико-економічний аналіз, китайські дослідники Ю. Чаї і Я. Юе досліджують історію та перспективи відносин Китаю та Латинської Америки ${ }^{5}$.

Значний інтерес становить стаття Дієго Лейве Ван де Маеле ${ }^{6}$, де через аналіз китайсько-латиноамериканських відносин XXI ст., висвітлюються три основні етапи їх розвитку. Новий погляд на реалізацію відносин між країнами представлений у роботі Х. Ніу ${ }^{7}$. Абсолютно новою є праця Дж. Малена ${ }^{8}$, яка присвячена впливу пандемії Covid-19 на розвиток відносин між Китаєм і країнами латиноамериканського регіону. Варто згадати i працю чилійського дослідника А. Боркеза ${ }^{9}$, який висвітлює розвиток китайськочилійських відносин у 2000-х роках. Натомість в українській історіографії дане питання залишається у колі малодосліджених питань.

Новий етап у розвитку китайсько-латиноамериканських взаємозв'язків припадає на 90-ті pp. ХХ ст. Саме в той час у країнах Латинської Америки та Карибського басейну (ЛАКБ) було прийнято низку неоліберальних реформ в економічній сфері, що згодом сприяло до відкритості національних економік і росту торговельних відносин з КНР, який перетворився на «світову фабрику» і потребував нових ринків збуту. У результаті проведених переговорних процесів, КНР і країни ЛАКБ підписали угоди про захист і заохочення інвестицій, а також про зняття подвійного оподаткування. Досить інтенсивно на той час розвивалися відносини Китаю з Венесуелою. Президент країни Уго Чавес здійснив низку візитів до КНР з метою активізації відносин. Перший з них відбувся у 1999 р., де глава Венесуели зазначив пріоритетність двостороннього співробітництва: «Китай - один 3 головних світових споживачів енергії, а Венесуела - один з головних світових постачальників енергії. Вони прекрасно доповнюють один одного» ${ }^{10}$.

Однак справжній прорив в активізації відносин Китай-Латинська Америка відбувся у XXI ст. Починаючи з 2001 р. Президент Китаю Цзян Цземінь здійснив низку візитів до країн регіону з метою обговорення політичних, економічних і військових проблем ${ }^{11}$.

У 2003 р. новий голова КНР Ху Цзіньтао у супроводі 300 підприємців і низки мініс-

\footnotetext{
${ }^{4}$ Lin Z., Johnson G. Sino-Latin American Relations: Chinese Views of Latin America. Washington, 2014. 42 p.

${ }^{5}$ Chai Yu, Yue Yunxia. Sino-Latin American Economic and Trade Relations. URL: https://www.springer.com/gp/book/9789811334047\#aboutAuthors

${ }^{6}$ Van de Maele, Diego Leiva. Xi Jinping and The Sino - Latin American Relations in The $21^{\text {st }}$ Century: Facing The Beginning of A New Phase? // Journal of China and International Relations (JCIR). 2017. Vol. 5, № 1. P. 35-67.

${ }^{7}$ Niu H. A New Era of China-Latin America Relations // Anuario de Integración. 2015. № 11. P. 39-51.

${ }^{8}$ Malena J. The impact of the pandemic on Latin America's relations with China. URL: https://asiapowerwatch.com/the-impact-of-the-pandemic-on-latin-americas-relations-with-china/

${ }^{9}$ Borquez A. Exploring the nontraditional foreign investment in Sino-Latin American relations: The Chilean case // SAGE Journals. 2020. Vol. 21. № 1. P. 18-33. DOI: 10.1177/1783591719877592

${ }^{10}$ Дабагsн Э. Китайское наступление в Латинской Америке // Политком.ru: Информационный сайт политических комментариев. 2013.27.09. URL: http//politcom.ru/16466.html

${ }^{11}$ Domínguez J.I. China's Relations With Latin America:Shared Gains, Asymmetric Hopes // Inter-American Dialogue. 2006. June. P. 2.
} 
трів зробив турне по чотирьом державам Латиноамериканського континенту: Бразилія, Аргентина, Чилі та Куба ${ }^{12}$. у 2004 р. в ході візиту на чилійський саміт АТЕС Ху Цзіньтао відвідав Бразилію, Аргентину, Кубу й інші країни континенту, а у 2005 р. відвідав Мекси$\mathrm{ky}^{13}$. На саміті був сформульований системний інтерес Китаю до Південної Америки для «спільного розвитку і співпраці». 3 кожним новим візитом стратегічні пріоритети Піднебесної у регіоні набували додаткових обрисів ${ }^{14}$.

У лютому 2007 р. віце-прем'єр КНР відвідав Аргентину, Еквадор, Барбадос і Багами. Паралельно інший віце-прем'єр Піднебесної побував у Бразилії, Колумбії, Мексиці та на Ямайці. Це унікальний випадок, коли чиновники такого високого рангу одночасно перебували на континенті ${ }^{15}$.

У листопаді 2008 р., після проведення Форуму країн ЛАКБ і Китаю китайське керівництво публікує документ «Політика Китаю в Латинській Америці і Карибському басейні», де політичне та економічне зближення КНР з країнами ЛАКБ пов'язано з просуванням стратегії «одного Китаю» і з прагненням домогтися визнання Пекіна, а не Тайваню, законним представником китайського народу ${ }^{16}$.

Так, збереження дипломатичних зв'язків Манагуа з Тайванем стало серйозною перешкодою для публічної заяви про підтримку проекту будівництва Нікарагуанського каналу з боку КНР. У 2013 р. «принцип єдиного Китаю» визнав і мексиканський уряд. А в 2017 р. - Панама ${ }^{17}$.

У 2009 р. стало зрозуміло, що крім нафти, сировини, бажання розвивати торгівлю та інвестиції, Пекін хотів би плавно форсувати своє «мирне піднесення» в тилу у США. Такі дії Китаю пояснюються бажанням продемонструвати Америці свій вплив і місце в Азійсько-Тихоокеанському регіоні (АТР) і змусили наддержаву рахуватися з інтересами. У результаті, китайське керівництво виділило три пріоритетних групи держав Латинської Америки: перша - «стратегічні партнери» (Бразилія, Мексика, Аргентина, Венесуела); друга - «партнери по співпраці» (Чилі, Перу, Куба); третя - «дружні партнери по співпраці» (країни Центральної Америки і Карибського басейну). Варто зазначити, що в основі такого неофіційного «розподілу» лежали комерційні, а не ідеологічні принципи ${ }^{18}$.

Упродовж 2010-2013 рр. й надалі спостерігається активізація політичного діалогу між країнами. 3 приходом до влади в КНР Сі Цзіньпіня політичні зв'язки між країнами стають більш динамічнішими. Так, у 2013 р. Сі Цзіньпін здійснив візит на Тринідад і Тобаго, в Коста-Ріку та Мексику.

Досить продуктивним у питанні розвитку дипломатичних відносин став 2014 р.

\footnotetext{
${ }^{12}$ Дабагян Э. Китайское наступление в Латинской Америке...

${ }^{13}$ Domínguez J.I. China's Relations With Latin America:Shared Gains, Asymmetric Hopes... P. 2.

${ }^{14}$ Лузянин С.Г. Китай в Латинской Америке: между идеологией и прагматизмом // МГИМО Университет: официальный сайт. 2013.28.01. URL:https://mgimo.ru/about/news/experts/234968/

${ }^{15}$ Дабагян Э. Китайское наступление в Латинской Америке...

${ }^{16}$ Борзова А.Ю., Торкунова Ю.А., Агав Ю.И. Китай - CELAC: новые тенденции в экономическом сотрудничестве // Латинская Америка. 2018. № 7. С. 32. DOI: 10.31857/S0044748X0000022-3

${ }_{17}^{17}$ Зерева В.С. Китай на просторах Латинской Америки: современные геополитические реалии // Вестник Московского государственного областного университета. Серия: История и политические науки. 2019. № 2 . C. 176. DOI: $10.18384 / 2310-676 \mathrm{X}-2019-2-171-183$

18 Лузянин С.Г. Китай в Латинской Америке: между идеологией и прагматизмом...
} 
Так, міністром закордонних справ КНР Ван I було здійснено візити до Куби, Венесуели, Аргентини, Бразилії (18 квітня 2014 р.), Гавани (19 квітня 2014 р.), де він провів зустріч 3 головою Державної ради та Ради міністрів Раулем Кастро і міністром закордонних справ Куби Бруно Родрігесом Паррилья. У рамках даного візиту велику увагу було приділено перспективам китайської участі у створенні спеціальної зони розвитку в порту Маріель, що мало посприяти залученню на Кубу іноземних інвесторів, модернізації економіки, підвищення рівня життя кубинців.

21 квітня 2014 р. китайська делегація відвідала Каракас. Ван I зустрівся з президентом Венесуели Ніколасом Мадуро та міністром закордонних справ країни Еліасом Хауа. У ході переговорів обговорювалися питання розширення співробітництва в сфері енергетики, зокрема, у нафтовій галузі. Піднімалася тема подальшої долі китайської програми 3 будівництва соціального житла у Венесуелі.

23 квітня 2014 р. китайський дипломат прибув до Буенос-Айресу, де відбулася його зустріч з президентом Аргентини Крістіною Фернандес де Кіршнер і міністром закордонних справ Ектором Тімерманом. Країни висловили свою зацікавленість у подальшому партнерстві. Акцент робився на продовольчій безпеці - експорті Аргентиною сільськогосподарської продукції до Китаю.

25 квітня того ж року глава МЗС КНР відвідав Бразилію, де провів переговори 3 президентом країни Ділма Руссефф і міністром закордонних справ Луїсом Альберту Фігейреду. Візит до Бразилії був також обумовлений підготовкою до шостого саміту БРІКС, який повинен був пройти в Бразилії у м. Форталеза 315 по 17 липня 2014 р. У ході зустрічі голова КНР Сі Цзіньпін наголосив про створення форуму «Китай - Спільнота латиноамериканських і карибських держав (CELAC)». Крім того передбачалося, що на бразильському саміті буде створено Банк розвитку БРІКС зі статутним капіталом у 50 млрд. доларів. У ході зустрічі було також обговорено питання можливої співпраці в галузі захисту електронних комунікацій Бразилії та Союзу південноамериканських націй (UNASUR) від вторгнення іноземних спецслужб - у першу чергу Агентства національної безпеки США, оскільки тема гучних викриттів Едварда Сноудена до сих пір залишається болючою та резонансною подією для бразильців.

Варто зазначити, що деякі експерти цей діловий вояж Ван I до країн Латинської Америки охрестили не стільки як крок до зміцнення взаємин з континентом, а як відповідь на політику США щодо Китаю. Оскільки, як відомо, Вашингтон неспокійно реагував і реагує на можливу консолідацію економік Азії. Приділяючи велику увагу АзіатськоТихоокеанському регіону, де має намір втілити амбітний проект транстихоокеанського партнерства (куди не запрошений Китай - найпотужніша економіка Азії), США створює свого роду санітарний кордон навколо КНР. Однак, не дивлячись на це, багато в чому успіхи китайської зовнішньої політики у латиноамериканському регіоні пояснюються позитивним іміджем КНР, оскільки економічна політика цієї держави будується на прагматичній взаємовигідній основі та невтручанні у внутрішні справи партнерів ${ }^{19}$.

У 2016 р. голова КНР відвідав Чилі, Перу й Еквадор з метою підняти рівень відносин

\footnotetext{
${ }^{19}$ Лосев А. Активизация сотрудничества между Латинской Америкой и Китаем // ИЛА РАН: Институт Латинской Америки Российской академии наук. 2014. Апрель. URL: http://www.ilaran.ru/?n=937
} 
3 цими державами ${ }^{20}$. Також Китай перетворився на основного азіатського партнера Мексики, пріоритет співпраці з яким знайшов відображення у Національному плані розвитку на 2013-2018 рр. Мексика і Китай зійшлися у думках щодо співпраці 3 питань забезпечення міжнародної стабільності та порядку, про що свідчить, наприклад, підтримка державами резолюції № 69/69 Генасамблеї ООН «Конвенції про заборону застосування ядерної зброї» від 2 грудня 2014 р..2.

Проте, Китай розвиває співробітництво з латиноамериканськими країнами не тільки на двосторонній основі, але й налагоджує зв'язки з регіональними організаціями. Китай здійснює співробітництво з державами ЛКА у рамках Азіатсько-Тихоокеанського економічного співтовариства (АTEC), G20, Міжнародного валютного фонду, Банку міжнародних розрахунків, Світового банку, СОТ, Ради з фінансової стабільності, Базельського комітету з банківського нагляду і СБ $\mathrm{OOH}^{22}$.

Китай взаємодіє з країнами Латинської Америки і на багатосторонніх платформах. Пекін отримав статус постійного спостерігача в Організації американських держав (ОАД) у 2004 р., увійшов до числа країн-донорів у Міжамериканський банк розвитку (МАБР) в 2009 р., що розширило участь КНР у фінансуванні проектів у регіоні нарівні із США та європейськими країнами. Китай став спостерігачем у Латиноамериканському парламенті (Parlamento Latinoamericano, PARLATINO), розширює зв'язки з Андським співтовариством (Comunidad Andina de Naciones, CAN), Співтовариством країн Карибського басейну (Caribbean Community, Caricom) та Американським спільним ринком (Mercado Común del Sur, Mercosur), із Союзом південноамериканських націй (Unión de las Naciones del Sur, Unasur), що утворився у 2004 р. й об’єднав 12 країн регіону ${ }^{23}$.

Принципово новим моментом став розвиток відносин Китаю зі Спільнотою країн Латинської Америки і Карибського басейну (Comunidad de los Estados Latinoamericanos y del Caribe, CELAC, 2011 р.), до складу якої ввійшли всі 33 держави ЛКА. У рамках CELAC був утворений Форум «CELAC - Китай», завданням якого стало розширення співпраці 3 Пекіном.

На зустрічі глав держав - членів CELAC і КНP 17 серпня 2014 р. у столиці Бразилії лідери дали офіційний старт проведення міжнародного форуму Китай - CELAC (Foro China - CELAC), і перша зустріч на рівні міністрів пройшла 8-9 січня 2015 р. в Пекіні. Виступаючи на цьому форумі, китайський лідер Сі Цзіньпін звертався до країн Латинської Америки як до єдиного цілого, озвучивши наміри своєї країни збільшити до 2025 р. товарообіг з латиноамериканськими державами до 500 млрд. дол. та інвестувати в економіку ЛАКБ 250 млрд. дол.

У прийнятій Пекінській декларації були представлені загальні принципи співробітництва, засновані на взаємній довірі і мирному розвитку, стратегії відкритості та взаємної вигоди в економічному співробітництві.

Зустріч на рівні міністрів, яка зібрала представників ЛКА та Китаю (33+1), стала знаковою подією, оскільки на ній був прийнятий «План по співробітництву Китаю і країн

\footnotetext{
${ }^{20}$ Зверева В.С. Китай на просторах Латинской Америки: современные геополитические реалии. С. 173.

${ }^{21}$ Ibid. C. 174.

${ }^{22}$ Ibid. C. 177.

${ }^{23}$ Борзова А.Ю., Торкунова Ю.А., Агав Ю.И. Китай - CELAC... С. 33.
} 
ЛАКБ на 2015-2019 рр.», що ознаменував новий період у взаємодії сторін. У цьому плані співпраця охоплювала практично всі життєво-важливі сфери: політику, безпеку, торгівлю, інвестиції, енергетику, природні ресурси, сільське господарство, промисловість, науку і технології, освіту, охорону здоров'я, туризм, спорт і т.д. Фактично план відображав створення повноцінного механізму політичного й економічного діалогу для взаємодії Китаю з усіма країнами регіону, про що заявив і міністр закордонних справ КНР Ван І.

Для реалізації плану були створені спеціалізовані структури, такі як: форум міністрів сільського господарства, бізнес-саміт, форум з розвитку енергетики, форум з розвитку інфраструктури, форум з питань співробітництва у сфері науки, техніки і інновацій, форум політичних партій, форум молодих політичних лідерів, форум аналітичних центрів Китаю і ЛАКБ, науково-технічна асоціація КНР і ЛАКБ, програма обміну інформацією тощо ${ }^{24}$.

24 листопада 2016 р. була опублікована оновлена Стратегія Китаю щодо Латинської Америки, де підкреслювалося, що КНР буде дотримуватися курсу, визначеного у плані зі співробітництва 3 країнами ЛАКБ до 2019 р. Як наголошувалося у документі, практичною реалізацією плану стає проект «1+3+6», де 1 означає єдину програму, 3 - три двигуна: торгівлю, інвестиції та фінансове співробітництво, 6 - шість головних напрямків: енергетика, природні ресурси, інфраструктура, сільське господарство, промисловість, інноваційні та інформаційні технології. Саме у ці галузі мала надходити рекордна кількість китайських інвестицій.

У рамках реалізації плану на 2015-2019 рр. між CELAC і KHР регулярно проводилися зустрічі підприємців. Так, на ХІ діловому саміті 2 грудня 2017 р. в Пунта-дель-Есте (Уругвай) зібралося понад 2500 бізнесменів (700 з КНР і 1800 з країн ЛАКБ), які обговорювали питання інфраструктури, логістики, агробізнесу та електронної торгівлі. Ця ділова зустріч фактично стала підготовчим заходом перед другим міністерським форумом CELAC - Китай, який відбувся в Чилі 21-22 січня 2018 р. під девізом «CELAC - Китай: робота заради поглиблення розвитку, інновацій та співпраці наших народів». На форумі розглядалися питання про розвиток зон вільної торгівлі (3BT) між CELAC і Китаєм, активізації фінансового співробітництва, розширення взаємодії у спільних інфраструктурних проектах.

Були також розроблені конкретні заходи по просуванню стратегічної співпраці в таких пріоритетних галузях, як політика і безпека, торгівля, інвестиції і сталий розвиток. Було також започатковано взаємодії в нових сферах - боротьба з корупцією, контроль над наркотиками і боротьба з кіберзлочинністю. Окрім того, були прийняті три ключові документи: Декларація Сантьяго, Спільний план китайсько-латино-карибського співробітництва (пріоритетні напрямки) на 2019-2021 рр., і Спеціальна заява з ініціативи «Один пояс і один шлях» ${ }^{25}$.

Окрім Форуму «Китай - CELAC», КНР співпрацює з країнами Латинської Америки у рамках Ініціативи «Шовкового шляху», яка була проголошена Китаєм у 2013 р. і стала одним 3 найамбітніших проектів. Ця ініціатива охоплює 64 країни Азії, Африки, Латинської Америки та Європи (63\% населення Землі) і націлена на розвиток аграрної промис-

\footnotetext{
${ }^{24}$ Борзова А.Ю., Торкунова Ю.А., Агав Ю.И. Китай - CELAC... С. 34.

${ }^{25}$ Ibid. C. 34-35.
} 
ловості у країнах, будівництво інфраструктурних об’єктів - портів, контейнерних терміналів, залізних і шосейних доріг, електростанцій і заводів.

Для реалізації проекту Пекін заснував Фонд Шовкового шляху у 40 млрд. дол., Азіатський банк інфраструктурних інвестицій (Asian Infrastructure Investment Bank, AIIB) 3 капіталом у 100 млрд. дол., який почав діяти 29 червня 2015 p. $^{26}$.

Також співробітництво між країнами відбувається у рамках ініціативи «Пояс і шлях», яка орієнтована і на країни Африки. Так, на саміті міжнародного співробітництва у травні 2017 р. президенти Аргентини та Чилі і представники міністрів 3 майже 20 країн Латинської Америки та Карибського басейну прокоментували, що Китай та Латинська Америка можуть використовувати цю ініціативу як вихідну точку до активного та рівноправного діалогу. Тим самим посилити співпрацю в економіці, торгівлі, науці і техніці, фінансах, культурі, гуманітарних та інших секторах. Було також зазначено, що розвиток політичної складової, сприятиме економічним зв'язкам між азіатським і латиноамериканським регіонами у цілому. Водночас це сприяє миру та розвитку світу. Окрім того, представники КНР і латиноамериканських країн заявили про майбутню організацію проекту «Китайсько-латиноамериканська спільнота спільної долі» («China-Latin America Community of Common Destiny»), метою якої $є$ забезпечення високого рівня консенсусу щодо передумов і підтримки координації політики, взаємодії між собою у плануванні розвитку відносин між країнами. Так звані «П'ять зв'язків» стануть важелем, який рухатиме практичну співпрацю між Китаєм і Латинською Америкою, засновану на фундаментальних принципах «досягнення спільного зростання за допомогою обговорення та координації» взаємовигідної співпраці ${ }^{27}$.

Дещо нового формату набули відносини Китаю з Латинського Америкою упродовж 2019-2020 рр., що пов'язано з початком пандемії COVID-19. Опинившись перед серйозним викликом і загрозою життю людства, Китай формує нову архітектоніку розвитку відносин $з$ країнами даного континенту. Яскравим прикладом можуть послугувати відносини Китай-Чилі. Так, під час своєї телефонної розмови з президентом Чилі 15 грудня 2020 р. Сі Цзіньпін зазначив, що зіткнувшись з пандемією COVID-19, обидві сторони об’єднують зусилля у боротьбі з нею і разом долають тимчасові труднощі. Китай у відносинах з Чилі просуває політику реформ і відкритості на ще більш високому рівні, що надасть більш широкий ринок і можливості для розвитку всіх країн світу, включаючи Чилі. Китайська сторона готова розширювати масштаби інвестицій у галузі сільського господарства, гірничодобувної промисловості та будівництва інфраструктури в Чилі, а також співпрацювати у сферах науково-технічних інновацій і цифровій економіці. Китай готовий поглиблювати зв'язки та співробітництво у галузі культури, освіти, охорони здоров'я та туризму.

Китайська сторона також готова активізувати співпрацю у питаннях розробки і використання вакцин, наданні допомоги Чилі у боротьбі з епідемією. Сі Цзіньпін додав, що китайська сторона налаштована зміцнювати контакти та координацію по пунктах глобального порядку денного, включаючи сталий розвиток і проблему зміни клімату, а також

\footnotetext{
${ }^{26}$ Ibid. C. 35.

${ }^{27}$ Wenhong Xu. Policy Coordination between China and Latin American Countries under the Framework of the Belt and Road Initiative // Outlines of Global Transformations. 2019. Vol. 12. № 3. P. 146.
} 
спільними зусиллями підтримувати мультилатералізм і вільну торгівлю. Він висловив надію, що чилійська сторона продовжить відігравати активну роль у рамках спільної співпраці між Китаєм і Латинською Америкою.

У свою чергу С. Піньєра підкреслив, що чилійська сторона високо оцінює важливі стратегічні успіхи Китаю у боротьбі з епідемією COVID-19 і відновленні зростання економіки. Він висловив упевненість у тому, що при розробці та здійсненні 14-го п'ятирічного плану китайська сторона надасть ще більші можливості всьому світу, в тому числі й Чилі. Чилійська сторона готова зміцнювати діалог і співробітництво 3 китайською стороною, активно брати участь у спільному будівництві «Пояси і шляхи», спільними зусиллями відстоювати справедливу та вільну торговельну систему, активізувати спілкування і координацію з важливих пунктів порядку денного, включаючи сталий розвиток і зміну клімату, а також спільно формувати «Спільноту єдиної долі людства» ${ }^{28}$.

Отже, починаючи з 1990-х років і до сьогодення КНР у питанні розвитку відносин 3 латиноамериканськими країнами вдалося досягти вражаючих результатів. Контакти між країнами відрізняються високим зустрічним ентузіазмом. Для низки країн регіону партнерство з Китаєм стало дійсно пріоритетним. Взаємодія Китаю з окремими латиноамериканськими державами відрізняється власною галузевою специфікою. Разом 3 тим Китай ставить перед собою політичні цілі, зокрема, у контексті «дипломатичної боротьби» 3 Тайванем за нових союзників, здатних на міжнародному рівні чинити підтримку ініціативам керівництва КНР. Політичному зближенню Китаю $з$ державами регіону ЛКА сприяє близькість позицій з ключових питань світового розвитку. Базовим принципом політики КНР у регіоні ЛАКБ виступає прагматичний підхід до питань економічної взаємодії незалежно від ідеологічної орієнтації держав.

\section{Liudmyla Vovchuk, Oleg Kravets}

\section{Development of Political and Diplomatic Relations Between the PRC and the Countries of Latin America (1990s-2020)}

Abstract: This article covers the development of political and diplomatic relations between the People's Republic of China (PRC) and Latin America. Seeking stability of energy security and world leadership, the Chinese government in the early 1990s declared cooperation with the countries of this continent as one of the priorities, although the establishment of contacts and diplomatic relations began before the collapse of the bipolar system of international relations. One of the first was pro-communist Cuba. Using the principle of «soft power», China is intensively developing these relations with Latin American countries. The importance of which they themselves say, calling China a priority partner.

A real breakthrough in the intensification of China-Latin America relations took place in the XXI century. Since 2001, Chinese President Jiang Zemin has made a number of visits to

\footnotetext{
${ }^{28}$ Председатель КНР Си Цзиньпин сегодня вечером провел телефонный разговор с президентом Чили Себастьяном Пиньерой // Синьхуа. Новости. 2020. 15 декабря. URL: http://russian.news.cn/202012/16/c_139592294.htm
} 
countries in the region to discuss political, economic and military issues. Jiang Zemin's successor, $\mathrm{Hu}$ Jitnao, continued the process of developing political dialogue with the countries of the continent. A number of visits were made to Brazil, Cuba, Argentina, Colombia, Mexico, Ecuador, etc. With each new visit, China's strategic priorities in the region took on additional shape. Also during this period, it became clear that China's relations with Latin America are not only a strategic cooperation, but also an opportunity for China to gradually accelerate its «peaceful rise» in the USA rear, due to China's desire to show America its influence and place in the AsiaPacific region take into account her interests.

With Xi Jinping's rise to power in China, political ties between the two countries have become more dynamic. Xi Jinping, like his predecessors, paid business and working visits to a number of Latin American countries, which resulted in the signing of various bilateral agreements on sharing cooperation.

However, China is developing cooperation with Latin American countries not only on a bilateral basis, but also establishing ties with regional organizations. China cooperates with the LCA countries in the framework of the Asia-Pacific Economic Community (APEC), the G20, the International Monetary Fund, and the Bank for International Settlements, the World Bank, the WTO, the Organization of American States, etc.

A fundamentally new moment was the development of China's relations with the Community of Latin America and the Caribbean (CELAC, 2011), which included all 33 LCA states. The CELAC-China Forum was established within the framework of CELAC, the task of which was to expand cooperation with Peking.

Thus, this article is an attempt by the authors in chronological order to highlight the development of relations between the countries until 2020, indicating the key aspects of this cooperation.

Keywords: PRC, Latin America, LAC, «soft power» diplomacy, political and diplomatic relations 